\title{
New Construction of Fire Fighting Academies Under the View of Information Construction
}

\author{
Bin Ni \\ Public Security Fire Control Forces Command Academy in Kunming, Yunnan, China \\ Corresponding Email: 578659400@qq.com
}

\begin{abstract}
With the rapid development of economy, we have entered the era of knowledgebased economy. With the rapid reform and innovation of science and technology, people's production and life style has undergone tremendous changes, especially the more and more indepth informatization, technicalization, networking and intelligentization of various trades and professions. In this paper, the author first explained the new changes brought by informatization to fire fighting academies at the different levels, and then combined with the actual construction of informatization of fire fighting academies, put forward feasible strategies to promote the management of informatization, providing a certain reference value for the development of informatization in fire fighting academies.
\end{abstract}

Keywords. Informatization, fire control construction, change, strategy, CIO.

\section{New changes brought by informatization to fire fighting academies}

\subsection{Flat organizational structure}

In the informatization era [1], the information interaction is more and more rapid and frequent, in order to ensure the high value of information use, improve the efficiency of information transmission, fire fighting academies are also developing toward the flat structure. Compared to the prior hierarchical bureaucratic management structure, the management scope of flattened organizational structure is widened, and the problem of duplication and multimanagement is reduced, which greatly improves the efficiency of academies, information transmission and feedback, so that the academies can understand and master the general situation in a timely and comprehensive manner, strengthen the communication efficiency among departments, facilitate the integration of teaching resources, promote exchanges between various departments, and make the work more standardized and institutional.

\subsection{Humanized management mode}

Human resources have become one of the core resources of competition among different trades and occupations, so the concept of "people-oriented" has become more and more popular among the people. As the main resource of resource utilization [2], integration and innovation, human resources play an important role in the process of academy development. In fire fighting academies, the main human resources include three parts: administrative management layer, teachers and students. Therefore, when applying the "people-oriented" management concept, the management of fire fighting academies should be fully mobilized to meet the management needs, respect teachers, care students, and constantly stimulate potentials. The self-management of teachers and students shall be taken as the goal, give full play to their own initiatives to achieve the optimization of resource management, to achieve a people-oriented and selfadministrative new trend.

\subsection{Learning campus atmosphere}

With the deepening of learning society, learning government and learning enterprise, the construction of learning campus has become the main trend of informatization, which is an inevitable requirement of social progress regarding academy development, so as to meet the requirements of the development of the times and train learning talents. As the education place of fire fighting professionals, fire fighting academies must establish the correct study orientation [3], create the learning atmosphere, construct a learning campus, and fully mobilize the value of mining all kinds of effective resources. Building a learning academy requires every teacher to strengthen self-learning and improvement, stimulate students' learning enthusiasm, render the atmosphere of academy learning, create a learning campus culture 
and atmosphere, and promote the academy reform and development, so that the academy will always keep vitality in the development process.

\section{Implementation strategy of informatization management in fire fighting academies}

\subsection{The basis of academy informatization management--the establishment of the academy informatization management evaluation system}

First, fire fighting academies shall actively promote and implement the establishment and promotion of the informatization management evaluation system as an important work in accordance with internationally recognized quality assurance system in the ISO9000 standards during construction of the system. In order to realize the wholeprocess development of academy management, fire fighting academies should actively introduce the "PDCA" standard and apply it in the whole process of informatization management to promote self-management and self-evaluation.

Second, the introduction of ISO9000 management standard system is the internationalized requirements of China's educational management. At presen, China's academies are still relatively backward, some of the more advanced academies already have their own management and evaluation system, but there are still many loopholes in the practice of the operation, management standards are not unified. Therefore, fire fighting academies should pay attention to the combination of their own situation in using and drawing lessons from the relevant management evaluation systems, refer to the school management and decision-making standards, take the mutual development of teachers and students as the management purpose, achieve proceduring academy management, inspire the enthusiasm of faculty and students, actively build a democratic, equal, transparent and scientific management system to promote orderly and sustained management, and to effectively guarantee the scientific management be strictly enforced and implemented.

Third, it is necessary to supervise the corresponding standards and systems in order to promote their continuous reform and innovation, and form a virtuous cycle of management of fire fighting academies. The ISO9000 management evaluation system of Fire fighting academies improves the normalization in running fire fighting academies, refines the management standards, making academy management more scientific and standardized, ultimately contributing to the perfection of academy management and promoting comprehensive and coordinated development of academies.

\subsection{Perfect ClO--Accountability mechanism of academy management}

CIO, namely the Chief Information Office, which is the school management responsibility system that we usually refer to, fire fighting academies can use computer and information management platform to manage the relevant information and help academy managers in analysis and decision-making. At present, management of fire fighting academies is not specific, informatization management is generally anchored in the network information center and can not grasp the full-range information, so the targeted allocation of existing teaching resources is difficult to be achieved.

On the one hand, a sound CIO should start from the following aspects: First, fire fighting academies should actively introduce high-quality and complex informatization management personnel, and constantly enrich academy management organization to improve the overall quality of the senior management team. Second, fire fighting academies shall conduct re-education and training of the relevant administrators of the existing school-related departments in accordance with the requirements of the learning-based campus, and constantly improve the overall quality of existing management workers. Third, it is necessary to make sure the posts and responsibilities of all departments and related personnel to be rationally distributed, to realize mutual supervision, clear power and responsibility, to establish and improve CIO responsible mechanism, and to improve the informatization of fire fighting academies management.

On the other hand, academies should make sure all managers in the CIO team are able to follow advanced educational philosophy, use technology-based means of education, with the help of computers, software and other equipment and platforms, in a comprehensive and accurate understanding of informatization, establish a sound fire fighting academies management informatization system, continue to guide academy management in the direction of technicalization and informatization, maximize the effectiveness of the existing funds, strive to maximize the value of academy management resources, help academies to develop appropriate reform strategies, improve the timeliness and accuracy of informatization management, so that managers of fire fighting academies can make rational allocation of school resources, make the decision of academy management more scientific, and keep close contact with various departments within the academy to improve the orderliness of informatization construction.

\subsection{Teacher's knowledge management--virtual teaching research}

The development of the knowledge economy era requires academies to adhere to the times and focus on the development and progress of the times, meanwhile, more knowledge growth and skill enhancement of teachers are required. Only comprehensive and good knowledge management can ensure that teachers' the invisible educational ideas and thoughts continue to reveal in the long-term education, the maximum play of the value of knowledge, and the best knowledge dissemination, so that knowledge can be deepened and continued. 
In the current era of informatization, teachers of fire fighting academies can use the virtual platform to improve the rigid form of traditional teaching methods and avoid the singularity and boringness of the form. In the course of concept teaching, we can strengthen the use of multimedia, simulation system, network teaching platform, on the one hand, it will let students understand the actual situation of fire control, on the other hand, it can also provide students with the form of network to combine theory and practice, enhance the quality and level of network teaching. The use of informatization platform for teaching can also break the limitations of time and space in teaching, so that students can learn and practice anytime and anywhere, not only forming more effective knowledge management, but also driving students' learning initiative, and gradually forming a knowledge management mode.

\subsection{An effective form of student management--virtual class management}

The "invasion" of network, database, multimedia, and other information modes in campus is making students' management work different from the past, the formation of virtual classes is a new student management method through the application of network technology, which is of great help to the management of students in fire fighting academies.

Teachers can build network files for fire fighting academy students by establishing a virtual class through the website or the home page to form a complete student electronic archives database. Through this way, on the one hand allows students to learn knowledge in the network, have fire fighting practice, but also allows students to carry out more teaching activities on the network platform. In addition, teachers can also communicate with the parents effectively to help students form correct values and outlooks on life. The construction of a network virtual class can also track the future development of the students, arrange the data of the students' employment situation, summarize the problems encountered in the students' work, and provide better service and help for the students. Students can get better help inside or outside the campus, at work or in life, enabling their professional skills to get a greater degree of promotion.

\section{Conclusion}

School information management not only aims at teaching and management via information technology means, more importantly, it aims to establish a sound informatization system in line with the practical situation of fire fighting academies, to help fire fighting academies build an informatization basis, establish appropriate scientific management rules and processes, and improve the level of informatization management through feedback and improvement in the continuous practice.

\section{References}

1. J.G. Zhang, Reflections on Teaching Strategies of Rescue Course in Fire Fighting Academies (Career Horizon, 2014)

2. H.C. Yang, Network Security Technology \& Application (2015)

3. W. Yan, The Guide of Science \& Education (Early Journal), 06 (2012) 